\title{
Populism and International Relations: (Un)predictability, personalisation, and the reinforcement of existing trends in world politics
}

\author{
Sandra Destradi ${ }^{1 \star}$ and Johannes Plagemann ${ }^{2}$ \\ ${ }^{1}$ Helmut Schmidt University / University of the Federal Armed Forces Hamburg and GIGA German Institute of Global and \\ Area Studies and ${ }^{2}$ GIGA German Institute of Global and Area Studies \\ ${ }^{*}$ Corresponding author. Email: Sandra.destradi@giga-hamburg.de
}

(Received 29 November 2018; revised 2 May 2019; accepted 10 May 2019; first published online 18 June 2019)

\begin{abstract}
As populists have formed governments all over the world, it becomes imperative to study the consequences of the rise of populism for International Relations. Yet, systematic academic analyses of the international impact of populist government formation are still missing, and political commentators tend to draw conclusions from few cases of right-wing populism in the Global North. But populism - conceptualised as a 'thin' ideology based on anti-elitism and anti-pluralism - takes different shapes across world regions as populists combine it with different 'thick' ideologies. To reflect such diversity and gain more systematic insights into the global implications of populism, we focus on cases of populist government formation in the Global South. We find that populists in power are not, per se, more belligerent or less willing to engage globally than their non-populist predecessors. Factors like status seeking or a country's embeddedness in international institutions mitigate the impact of populism. Its most immediate effect concerns procedural aspects: foreign policymaking becomes more centralised and personalised - yet, not entirely unpredictable, given the importance of 'thick' ideologies espoused by populist parties and leaders. Rather than changing course entirely, populists in power reinforce existing trends, especially a tendency towards diversifying international partnerships.
\end{abstract}

Keywords: Populism; International Relations; Global South; Foreign Policy

\section{Introduction}

One of the most prominent developments in world politics in recent years has been the rise to power of populists around the world. While Latin America has a long tradition of populists forming governments, the election of Donald Trump as president of the United States, the consolidation in power of populist governments in Hungary and Poland, the formation of an all-populist coalition government in Italy in June 2018, but also the rise to power of populist leaders in a range of non-Western countries, from Turkey to India and the Philippines, indicate that populism is here to stay and has become a global phenomenon. As populists take over executive and legislative powers, the implications of their rise become even more relevant for international politics. While populist parties can influence foreign policy by being junior partners in coalition governments $^{1}$ or by shaping the political discourse while in the opposition, ${ }^{2}$ the election of populist

\footnotetext{
${ }^{1}$ Bertjan Verbeek and Andrej Zaslove, 'The impact of populist radical right parties on foreign policy: the northern league as a junior coalition partner in the Berlusconi governments', European Political Science Review, 7:4 (2015), pp. 525-46.

${ }^{2}$ Matthijs Rooduijn, 'The mesmerising message: the diffusion of populism in public debates in western European media', Political Studies, 62:4 (2014), pp. 726-44.

(C) British International Studies Association 2019. This is an Open Access article, distributed under the terms of the Creative Commons Attribution licence (http://creativecommons.org/licenses/by/4.0/), which permits unrestricted re-use, distribution, and reproduction in any medium, provided the original work is properly cited.
} 
leaders and the formation of populist governments will have a much more immediate impact on the foreign policy of states and, by extension, on world politics. ${ }^{3}$

But how and under what conditions can we expect populism to actually impact on foreign policy, and what does the global rise of populism mean for world politics? If we drew conclusions from US foreign policy under Trump, we would envisage a whole range of worrying consequences of populists' ascent to power: a weakening of existing multilateral institutions; increasing failures in global public goods provision in crucial fields, from climate change mitigation to poverty reduction; a proliferation of international disputes due to an aggressive approach to international politics; and a rising unpredictability in world politics due to the populist leader's erratic leadership style. Such extrapolations from the case of Trump apparently find some confirmation in the foreign policies of populist governments in Europe - think of their scepticism $v i s-\grave{a}$-vis the European Union or of their policies on migration. Mainly drawing from cases of European populism, foreign policy observers tend to expect 'greater opposition to multilateral bodies like the EU, NATO and the WTO, and greater sympathy for Russia'. ${ }^{4}$ But is this necessarily the case, or are these features specific of Western populist governments? For instance, a recent study of India's foreign policy under the populist Prime Minister Modi reveals a substantial degree of continuity in the substance of the country's foreign policy - regardless of the formation of a populist government. ${ }^{5}$

In order to assess the potential international implications of the global rise of populism, we therefore need a more systematic approach that asks under what conditions the rise to power of populists will impact on their countries' foreign policy. To do so, we take a specific angle: we focus on the formation of populist governments in the Global South. Our core contention is that before we can reach any conclusions about the international consequences of the global rise of populism, we need a differentiated account of populist foreign policy that goes beyond the relatively well covered Western cases and a primary focus on right-wing populism. What seems useful is an approach that studies populists of different stripes and from different world regions and assesses in which ways their takeover impacts on their countries' foreign policy. We therefore analyse the foreign policies of India's Prime Minister Narendra Modi, Turkey's prime minister and, since 2018, President Recep Tayyip Erdoğan, Venezuela's late President Hugo Chávez, and the Philippines' President Rodrigo Duterte. Given the dearth of theorisations of populism's impact on foreign policy and world politics, we focus our analysis on three broad areas in which populism can be expected to be particularly consequential. With reference to established concepts of populism as well as the literature from Foreign Policy Analysis, we ask in how far and under what conditions populists in power contribute to: (a) more conflict-prone bilateral relations; (b) a weakening of global governance and its institutions; and (c) a more centralised and personalised foreign policymaking.

Before moving on to the discussion of single aspects of populism and world politics, we need to clarify what our understanding of populism is. We then develop expectations about the impact of populist government formation on foreign policy and use the analysis of contemporary cases in the Global South to examine to which extent other factors mitigate the impact of populism. Our main findings are the following: Due to structural conditions and to the impact of different 'thick' ideologies, populists in power do not automatically behave like worse international citizens as compared to their non-populist predecessors. Moreover, populists in power tend to reinforce existing trends in world politics rather than change course entirely. While foreign policymaking

\footnotetext{
${ }^{3}$ Angelos Chryssogelos, 'Populism in foreign policy', in Oxford Research Encyclopedia of Politics (2017), available at: \{doi: 10.1093/acrefore/9780190228637.013.467\}; NIC, 'Global Trends: Paradox of Progress' (Washington: National Intelligence Council, 2017), available at: \{www.dni.gov/nic/globaltrends\} accessed 29 August 2018; Daniel Drezner, 'The angry populist as foreign policy leader: Real change or just hot air?', The Fletcher Forum for World Affairs, 41:2 (2017), pp. 23-43.

4'A dangerous waltz', The Economist (3 February 2018), pp. 17-19.

${ }^{5}$ Johannes Plagemann and Sandra Destradi, 'Populism and foreign policy: the case of India', Foreign Policy Analysis, 15:2 (2019), pp. 283-301.
} 
certainly becomes more centralised and personalised under populist leaders, strong 'thick' ideologies reduce their unpredictability and arbitrariness.

\section{Populism and IR}

Among the many different ways to conceptualise populism, the economic-structuralist approach probably has the longest tradition. In the 1960s-1980s, scholars of populism used to define this concept by looking at 'irresponsible' distributive policies and the political role of constituencies like organised workers. ${ }^{6}$ Later, when in Latin America a range of leaders started combining populist traits with neoliberal economic policies, populism came to be conceptualised as a political strategy used by 'a personalistic leader [who] seeks or exercises government power based on direct, unmediated, uninstitutionalized support from large numbers of mostly unorganized followers.' 7 Such a narrow focus on a personalistic leader and on unorganised masses, however, was criticised by authors interested in organised forms of populist politics, including populist parties. $^{8}$ A more recent, alternative way to think of populism considers it a political style. In that case, the focus is on populists' bad manners and performance of crisis. ${ }^{9}$ Such an approach captures several interesting elements of contemporary populist leaders' political communication strategy. However, it has the disadvantage of remaining limited to rather superficial features while ignoring populism's deeper ideological elements.

The contemporary debate on populism has been substantially shaped by approaches that take an ideational perspective and consider populism a 'thin-centred ideology'. ${ }^{10}$ Such approaches focus on what constitutes the ideational and ideological core of populism. In other words, they address the very essence of populism, regardless of the economic policies resulting from it, the peculiarities of its mobilisation strategies, or the style preferred by its leaders. Thereby, an ideational approach has the advantage of highlighting the commonalities of different types of populist leaders and movements across the political spectrum. This is important as populist 'thin' ideology typically coexists with 'thicker' ideological elements such as nationalism, socialism, or religious fundamentalism. $^{11}$

The two essential traits of the thin populist ideology are anti-elitism and anti-pluralism. ${ }^{12}$ Populists typically portray elites as a predatory class detached from and opposed to a 'morally pure and fully unified' people. ${ }^{13}$ In that sense, populists separate society into 'two homogeneous and antagonistic groups, "the pure people" and "the corrupt elite". ${ }^{14}$ Obviously, such depictions are highly moralistic: populist discourses imply a Manichean worldview in which the 'people' is good and elites are 'evil'. ${ }^{15}$ Relatedly, populists tend to portray the people, and themselves, as victims in their own lands, so that ultimately 'majorities act as mistreated minorities'. ${ }^{16}$ What counts as predatory elite varies according to the thick ideology espoused. Trump habitually attacks the Washington establishment ('drain the swamp'), Thaksin in Thailand targeted the country's aristocratic network Amaat, Euro-populists dwell on their disdain for the EU bureaucracy, and Latin

\footnotetext{
${ }^{6}$ Kurt Weyland, 'Clarifying a contested concept: Populism in the study of Latin American politics', Comparative Politics, 34:1 (2001), pp. 4-9.

${ }^{7}$ Ibid., p. 14.

${ }^{8}$ Paris Aslanidis, 'Is populism an ideology? A refutation and a new perspective', Political Studies, 64:1, suppl. (2015), p. 96.

${ }^{9}$ Benjamin Moffitt, The Global Rise of Populism: Performance, Political Style, and Representation (Stanford: Stanford University Press, 2016).

${ }^{10}$ Cas Mudde, 'The populist zeitgeist', Government and Opposition, 39:4 (2004), p. 544.

${ }^{11}$ Ibid.; Cas Mudde, 'Europe's populist surge: a long time in the making', Foreign Affairs, 95:6 (2016).

${ }^{12}$ Jan Werner Müller, What Is Populism? (Philadelphia: University of Pennsylvania Press, 2016).

${ }^{13}$ Ibid., p. 19.

${ }^{14}$ Ibid., p. 26

${ }^{15}$ Mudde, 'The populist zeitgeist', p. 543; Kirk A. Hawkins, 'Is Chávez populist?: Measuring populist discourse in comparative perspective', Comparative Political Studies, 42:8 (2009), pp. 1043-4.

${ }^{16}$ Müller, What Is Populism?, p. 42.
} 
American leftist populists aim at transnational capital and particularly at US businesses and their domestic affiliates. Anti-elitism often comes along with calls for a radical break with the past. Populists promise a "rupture" with the existing unjust order" ${ }^{17}$ that has been maintained by its elitist beneficiaries against the interest of the morally pure people.

The second core feature of populism derives from populist leaders' claim that 'they, and they alone, represent the people'. ${ }^{18}$ Again, what counts as the 'righteous and morally pure ${ }^{19}$ people varies depending on the thick ideology; yet, such definitions routinely involve the exclusion of certain parts of society, often ethnic or religious minorities. However, populists' anti-pluralism does not necessarily coincide with nativism. Left-wing populists usually oppose ethnonationalism, but their claim to represent the true people also excludes political competitors and their constituencies. A related feature of populism is its embrace of personalised power by a charismatic leader who claims to embody the popular will. This aspect feeds into populists' characteristic disdain for checks and balances as well as minority rights. ${ }^{20}$ Intermediate institutions, from parliament, courts, and the media to civil society activists, are portrayed as elitist instruments for the control or abuse of the true people. ${ }^{21}$ Correspondingly, populist leaders enthusiastically endorse new communication media, while traditional media 'are accused ... of "mediating" [and thereby] distorting political reality. ${ }^{22}$

Whereas the domestic drivers and implications of populism have been studied extensively, research on populism and foreign policy - and even more so on populism and IR - is still in its infancy. Among the few exceptions are works that focus on populist parties in coalition governments. ${ }^{23}$ Moreover, some studies address the relationship between populism and foreign policy in a more systematic manner, but with a clear Western bias; ${ }^{24}$ a narrow focus on populist radical right parties (outside government) in Europe; ${ }^{25}$ or an emphasis on the personalities of 'angry' populist leaders. ${ }^{26}$

Bertjan Verbeek and Andrej Zaslove focus on populist political parties, not on populists in power. ${ }^{27}$ Based on insights from a range of Western and Latin American cases, they develop a typology of populist foreign policy positions in four fields that are particularly relevant to the European populist discourse: regional integration, trade and finance, migration, and 'general attitude' (understood mainly along a nationalist/isolationist/protectionist vs cosmopolitan continuum). Their core argument is that populist parties will not automatically adopt identical foreign policy positions. ${ }^{28}$ What matters more is populists' thick ideology. For example, scepticism of regional integration, protectionism, anti-migration stances, and isolationism are typical for populist radical right parties, but not for market liberal populists, for regionalist populists, nor for left-wing populists.

\footnotetext{
${ }^{17}$ Francisco Panizza and Romina Miorelli, 'Populism and democracy in Latin America', Ethics and International Affairs, 23:1 (2009), p. 40, emphasis in original.

${ }^{18}$ Müller, What Is Populism?, p. 3.

${ }^{19}$ Ibid.

${ }^{20}$ Ibid., pp. 31-2.

${ }^{21}$ Ibid., p. 31.

${ }^{22}$ Ibid., p. 35.

${ }^{23}$ Verbeek and Zaslove, 'The impact of populist radical right parties on foreign policy'.

${ }^{24}$ Bertjan Verbeek and Andrej Zaslove, 'Populism and foreign policy', in Cristóbal Rovira Kaltwasser et al. (eds), The Oxford Handbook of Populism (Oxford: Oxford University Press, 2017), pp. 384-405; Rosa Balfour et al., 'Europe's Troublemakers: The Populist Challenge to Foreign Policy’ (Brussels: European Policy Centre, 2016), available at: \{http:// www.epc.eu/pub_details.php?cat_id=17\&pub_id=6377\} accessed 20 November 2018.

${ }^{25}$ Christina S. Liang, 'Europe for the Europeans: the foreign and security policy of the populist radical right', in Christina S. Liang (ed.), Europe for the Europeans: The Foreign and Security Policy of the Populist Radical Right (Aldershot: Ashgate, 2007), pp. 1-32.

${ }^{26}$ Drezner, 'The angry populist as foreign policy leader'.

${ }^{27}$ Verbeek and Zaslove, 'Populism and foreign policy'.

${ }^{28}$ Ibid., p. 392.
} 
Angelos Chryssogelos similarly calls for a nuanced approach to the analysis of populist foreign policy while searching for the elements that 'are themselves a function of traits of populist ideology tout court'. ${ }^{29} \mathrm{He}$ argues that populists' domestic anti-elitism can explain their opposition to international elites and particularly to the US; that their notion of protecting and representing the 'people' can explain their suspicion of international or transnational institutions; and that their definition of the 'people' can transcend national boundaries. While not systematically testing these propositions, Chryssogelos draws on examples from different world regions in a first attempt to specifically address the peculiarities of populist foreign policy. He also argues that 'populists will engage with the world, but only in terms that favour immediate national interests', that sovereignty will be one of their priorities, and that ' $\mathrm{t}$ ] he exact content of populist foreign policies will differ according to the thicker ideologies these parties and movements express.'

In a first systematic effort at theorising populist foreign policy, Plagemann and Destradi carry out a plausibility probe for a set of hypotheses for the case of India under Prime Minister Modi. ${ }^{30}$ They conclude that the formation of a populist government in India has not had the expected impact on the substance of foreign policy. Rather, other factors like India's striving for greatpower status seem to have mitigated the impact of populism. By contrast, populism in India has had a substantial impact on the procedural aspects of foreign policymaking as well as its communication, including with India's large diaspora.

The findings from these recent studies therefore suggest that we need a nuanced understanding of populism and international politics that considers both populism's implications for foreign policymaking domestically (that is, procedural aspects) and a country's positioning within international affairs more broadly. This is where our contribution sets off. We structure it along three interrelated thematic lines: populists' readiness to escalate international conflicts; populists' willingness to contribute to global public goods provision and to cooperate in international institutions; and populists' centralisation and personalisation of foreign policymaking. These themes are frequently mentioned in debates on the international dimensions of populism, but have not been systematically assessed in previous works. We intentionally exclude more specific traits commonly attributed to populists' foreign relations, such as a preference for protectionism or an antiimmigrant stance, which have been found to be primarily related to thick ideologies. ${ }^{31}$ Instead, as an attempt in theory building, we focus on those areas which resonate most with the theory of populism as a thin ideology and can thereby reveal commonalities of populists' approaches to world politics all across the political spectrum.

We base our discussion on empirical evidence from a range of cases in the Global South. Given the dearth of theorisations on populism and international politics, we take an exploratory approach. Instead of pursuing a strict comparative design, we carry out within-case comparisons between populists in power and the respective preceding, non-populist governments. This allows us to focus on the changes that take place once populists come to power and form governments. Our qualitative analysis draws on a range of source materials, including academic secondary sources, think tank and local media reports as well as primary sources such as populist leaders' speeches and data on global governance contributions like UN peacekeeping troop strength or development aid expenditures. ${ }^{32}$ We assess cases from different world regions, with different thick ideologies, durations in power, structural positions in the international system, and degrees of embeddedness in international institutions. This allows us to gain insights into the factors that might mitigate or exacerbate the impact of populism on foreign policy. We only consider contemporary or relatively recent cases of populists in power. This is so because we think that the

\footnotetext{
${ }^{29}$ Chryssogelos, 'Populism in foreign policy'.

${ }^{30}$ Plagemann and Destradi, 'Populism and foreign policy'.

${ }^{31}$ Verbeek and Zaslove, 'Populism and foreign policy'.

${ }^{32}$ For the case of India, we also draw on interviews with diplomats and experts in part carried out for our previous research on India's foreign policy.
} 
international context within which populists exercise their foreign policies matters. Thus, whereas historical cases within grossly different international contexts (for example, the Cold War) may yield interesting insights for future research, they may also include restraining factors (for example, alliance systems) that limit their findings' applicability to current world affairs.

Our cases include India, where Prime Minister Modi, who has been governing with a strong majority since 2014, clearly combines the anti-elitist and anti-pluralist features of populism. Modi stylises himself as a self-made man of humble origins and he has been vocally critical of the corrupt established political elite of the preceding Indian National Congress-led governments. At the same time, under the Modi government we have seen a rise of openly anti-pluralistic tendencies $v i s$ - $a$-vis Muslims and other minorities. ${ }^{33}$ Modi's populism espouses the Hindu-nationalist thick ideology of his Bharatiya Janata Party (BJP), which centres on the notion of Hindutva - the equation of Indian identity with Hindu civilisation and Hinduism. ${ }^{34}$

Turkey's Recep Tayyip Erdoğan served as prime minister for three terms (2003-07, 2007-11, 2011-14). In 2014, he was elected president of Turkey and, after a contentious constitutional reform and an electoral victory, he was sworn in as executive president in July 2018. With Erdoğan we can see a populist takeover. His Justice and Development Party (Adalet ve Kalkınma Partisi, AKP) has pursued an anti-elitist, anti-establishment project, 'reviv[ing] the spirit of the "Anatolian revolution" against Kemalist elitism' ${ }^{35}$ and creating 'a fault line between deprived ordinary people ... and privileged elites guarded by the military'. ${ }^{36}$ Moreover, Erdoğan embodies the anti-pluralist element of populism by claiming to be 'the only one who can understand [the people's] demands ... at the expense of pluralism and democratic institutions'. ${ }^{37}$ The underlying thick ideology pursued by Erdoğan has been Islamism, as opposed to his predecessors' secular (allegedly 'elitist') Kemalism. ${ }^{38}$

As a 'textbook' case of a radical leftist populist in power, we look at Hugo Chávez, the president of Venezuela from 1999 until his death in 2013. His strident anti-establishment rhetoric, his self-understanding as the true representative of the popular will, ${ }^{39}$ but also the limitations he imposed on the opposition ${ }^{40}$ allow us to unequivocally consider Chávez a populist.

Rodrigo Duterte, who was elected president of the Philippines in 2016, came to power by 'skillfully present [ing] himself as the underdog, a simple folk and provincial mayor audaciously taking on the "big machine" and "Imperial Manila" elites'. ${ }^{41}$ His anti-establishment attitude is paired with a provocative political style, a disregard for institutional checks and balances, and with antipluralism. ${ }^{42}$ The 'other' in his 'demonology [are] not ... abstract structural factors ("globalisation" and "capitalism") like that of "left populists" but rather ... a specific group deemed sub-human and worthy of extermination: drug dealers and users'. ${ }^{43}$ Duterte does not combine his populism

\footnotetext{
${ }^{33}$ Plagemann and Destradi, 'Populism and foreign policy'.

${ }^{34}$ Christophe Jaffrelot, 'India's democracy at 70: Toward a Hindu state?', Journal of Democracy, 28:3 (2017), pp. 52-3.

${ }^{35}$ Cengiz Günay, 'Foreign policy as a source of legitimation for "competitive authoritarian regimes": the case of Turkey's AKP', Georgetown Journal of International Affairs, 17:2 (2016), p. 41.

${ }^{36}$ Burak B. Özpek and Nebahat T. Yaşar, 'Populism and foreign policy in Turkey under the AKP rule', Turkish Studies, 19:2 (2018), p. 206.

${ }^{37}$ Bilge Yabanci, 'Populism as the problem child of democracy: the AKP's enduring appeal and the use of meso-level actors', Southeast European and Black Sea Studies, 16:4 (2016), pp. 599-600.

${ }^{38}$ Burak Cop and Özge Zihnioğlu, 'Turkish foreign policy under AKP rule: Making sense of the turbulence', Political Studies Review, 15:1 (2015), p. 29.

${ }^{39}$ Cas Mudde and Cristóbal Rovira Kaltwasser, Populism: A Very Short Introduction (Oxford: Oxford University Press, 2017), pp. 16-17.

${ }^{40}$ Ibid., p. 32.

${ }^{41}$ Richard J. Heydarian, The Rise of Duterte: A Populist Revolt against Elite Democracy (Singapore: Palgrave Pivot, 2018), p. 33.

${ }^{42}$ Ibid., p. 9.

${ }^{43}$ Mark Thompson, 'Bloodied democracy: Duterte and the death of liberal reformism in the Philippines', Journal of Current Southeast Asian Affairs, 35:3 (2016), p. 51.
} 
with a full-fledged 'thick' ideology. Instead, he has strategically mixed right- and left-wing ideological elements to secure support from very diverse domestic constituencies. ${ }^{44}$ On the one hand, his approach has been called 'illiberal "right" 45 and, according to some, it even entails fascist elements; ${ }^{46}$ on the other, Duterte has called himself as a leftist, ${ }^{47}$ and has cultivated close links with members of the Communist Party and leftist rebel groups. ${ }^{48}$

\section{A more conflict-prone world?}

Are populists, once they come to power, more likely to initiate or escalate international disputes than their non-populist predecessors? Anecdotal evidence suggests that populists pursue a more ruthless and confrontational foreign policy course as compared to their non-populist counterparts - think of Trump's hostility to Mexico or of his definition of the EU as a 'foe'. As one observer put it, former British Foreign Secretary Boris Johnson and US President Trump 'share ... a recklessness that looks like courage in the eyes of their supporters, but which also sabotages the work of policymaking and diplomacy. ${ }^{49}$ In theoretical terms, such recklessness might indeed be a result of populists' tendency to portray the world in simplistic terms of good vs evil. This could ultimately lead to a proliferation of international disputes and a less peaceful world. Populists' defence of a 'true' people - whom allegedly they alone represent - might induce them to be less inclined to compromise in international disputes.

Moreover, a typical feature of populists in power is the continuous mobilisation of their support base. As they effectively become the much-despised 'elite' themselves once in government, populists need to 'perpetuate an anti-elitist stance ${ }^{50}$ in a new way. They might do so by portraying themselves as victims (of the press, judiciary, or other domestic institutions), or by blaming 'elites acting behind the scenes, whether at home or abroad's1 for any of their failures. Moreover, the claim to be the true representatives of the people is in constant need for performative verification. Thus, as Jan Werner Müller puts it, populists are permanently on the campaign trail and they 'continue to polarize'. ${ }^{52}$ A politicisation of selected international issues for domestic mobilisation (rally around the flag) can therefore be expected to be particularly intense under populist governments. ${ }^{53}$

However, we do not expect populists to indiscriminately adopt a more aggressive foreign policy. Instead, their use of foreign policy for domestic mobilisation should reflect a combination of their populist 'thin' ideology (anti-elitism and anti-pluralism) with their underlying 'thick' ideology. Depending on their 'thick' ideology, populists may exclude specific sections of the population from their definition of the 'real' people (for example, migrants, or members of certain minorities). In that case, we can expect populists in power to target foreign countries that are closely associated with such excluded section of their population - primarily for domestic mobilisation purposes. Populists might also be more willing to support 'the people' abroad against

\footnotetext{
${ }^{44}$ Ibid., p. 53.

${ }^{45}$ Ibid., p. 51.

${ }^{46}$ Walden Bello, 'Rodrigo Duterte: a fascist original', Foreign Policy in Focus (6 January 2017), available at: \{https://fpif.org/ rodrigo-duterte-fascist-original/\} accessed 29 August 2018.

${ }^{47}$ Nicole Curato, 'Flirting with authoritarian fantasies? Rodrigo Duterte and the new terms of Philippine populism', Journal of Contemporary Asia, 47:1 (2017), p. 146.

${ }^{48}$ Mong Palatino, 'Is the Philippines' Duterte really a leftist?', The Diplomat (2 May 2017).

${ }^{49}$ William Davies, 'Boris Johnson, Donald Trump and the rise of radical incompetence', The New York Times (13 July 2018), available at: \{https://www.nytimes.com/2018/07/13/opinion/brexit-conservatives-boris-trump.html\} accessed 29 August 2018.

${ }^{50}$ Muller, What Is Populism?, p. 41

${ }^{51}$ Ibid.

${ }^{52}$ Ibid.

${ }^{53}$ 'Lexington: the threat within', The Economist (7 July 2018), p. 40.
} 
actors hostile to them, and thereby to meddle with the internal affairs of the countries that host such diaspora.

Similarly, depending on their 'thick' ideology, populists will have different understandings of what counts as 'elite'. Again, we can expect this understanding to shape a more conflictual attitude towards single countries that are identified with such elite. All of this is particularly likely to lead to the initiation or escalation of international disputes with specific international actors, but not necessarily to a generally more polarising, conflictive approach to world politics.

The cases analysed broadly confirm these expectations. Among the most glaring examples of a conflation of the domestic definition of the 'real people' with an international dimension is Turkey's approach to the Kurdish issue and its role in the war in Syria: 'The Kurdish dimension of the Syrian conflict has induced President Erdoğan to go as far to define the conflict as a domestic issue. ${ }^{54}$ After the AKP's electoral victory in 2011, the revisionist tone in Turkey's foreign policy has become more pronounced, and a general resecuritisation of Turkish foreign policy took place after the outbreak of civil war in Syria. ${ }^{55}$ This culminated in the Turkish army entering Kurdish-held Syrian territory in early 2018. Likewise, Erdoğan's domestic prosecution of the Gülen movement has had repercussions for his foreign policy. It has led to tensions with the US due to Turkey's repeated requests to extradite the movement's leader, as well as to pressures on other countries to persecute the organisation. ${ }^{56}$

In the case of India, the main section of the population excluded from the BJP's anti-pluralistic conception of the 'real people' are Muslims. However, this did not translate into a hostile foreign policy vis-à-vis Muslim countries generally. In fact, one of the Modi government's most significant foreign policy achievements was an agreement on land boundaries with neighbouring Bangladesh, a predominantly Muslim country. And while improving India's relations with Israel, Modi also travelled to the UAE, Saudi Arabia, Iran, and Qatar, reflecting his efforts towards diversifying and expanding India's international partnerships in all directions. ${ }^{57}$

Modi's anti-Muslim stance is most closely associated with hostility vis-à-vis Pakistan - the country that was created as a homeland for former British India's Muslims. Modi's non-populist predecessors, not only from the secularist Indian National Congress, but also from the Hindu-nationalist BJP, had since the early 2000s pursued a predominantly moderate approach towards Pakistan. Modi's policy, in turn, was initially a 'curious amalgam of ideology and pragmatism' ${ }^{58}$ However, after two years in office, Modi started to adopt a more explicit anti-Pakistan rhetoric and a more 'muscular' approach. This included the first public acknowledgement by an Indian government of having carried out 'surgical strikes' against militants on territory controlled by Pakistan in 2016. Domestically, this was accompanied by the branding of people expressing positive views about Pakistan as 'anti-national'. In response to a terrorist attack in early 2019, the Indian Air Force for the first time since 1971 entered Pakistani territory to shell what the Indian government claimed was a terrorist camp. Anti-Pakistan rhetoric was a major element in Modi's populist election campaign of 2019, revealing the link between domestic mobilisation and foreign policy. ${ }^{59}$ Yet, despite a clearly more bellicose rhetoric and a challenge to Pakistan, the

\footnotetext{
${ }^{54}$ Günay, 'Foreign policy as a source of legitimation', pp. 42-3.

${ }^{55}$ Burak B. Özpek and Yelda Demirağ, 'Turkish foreign policy after the "Arab Spring": From agenda-setter state to agenda-entrepreneur state', Israel Affairs, 20:3 (2014), pp. 328-46.

${ }^{56}$ Asli Aydintasbas, 'The Good, the Bad, and the Gülenists: The Role of the Gülen Movement in Turkey's Coup Attempt' (London: ECFR, 2016), p. 9, available at: \{https://www.ecfr.eu/publications/summary/the_good_the_bad_and_the_gulenists7131\} accessed 29 August 2018.

${ }^{57}$ Ian Hall, 'Multialignment and Indian foreign policy under Narendra Modi', The Round Table, 105:3 (2016), pp. $271-86$.

${ }^{58}$ Sumit Ganguly, Hindu Nationalism and the Foreign Policy of India's Bharatiya Janata Party (Washington: Transatlantic Academy, 2015), p. 12.

${ }^{59}$ See, for example, 'Congress responsible for the creation of Pakistan, says Narendra Modi', Economic Times (9 April 2019), available at: https://economictimes.indiatimes.com/news/elections/lok-sabha/india/congress-responsible-for-creationof-pakistan-says-narendra-modi/articleshow/68791722.cms accessed 14 April 2019.
} 
worsening of India's relations with Islamabad has so far not been as dramatic as to lead to fullfledged war.

A good illustration of how populists' different definitions of the 'elite' impact on foreign policy is their approach to the US. In fact, one interesting commonality among most of the Global South countries analysed here is the worsening of relations with the US after the formation of populist governments. Depending on their underlying thick ideology, populists equated the US with a global elite with different characteristics. For Chávez and other radical leftist populists, the US epitomise a transnational capitalist elite, and anti-Americanism is synonymous with an anti-imperialist policy. Correspondingly, under Chávez, anti-Americanism became the driving force of Venezuela's foreign policy (including some constructive traits such as the promotion of regional cooperation in South America ${ }^{60}$ or the provision of leadership to OPEC). ${ }^{61}$ Duterte also mixes his resentment against 'imperial Manila' with anti-imperialism directed at the US, ${ }^{62}$ thereby questioning Manila's traditional 'special relationship' with Washington. ${ }^{63}$ While less openly anti-American initially, Erdoğan's Turkey gradually drifted away from the country's established Western partners, ${ }^{64}$ in line with a foreign policy shift towards the Middle East and Eastern and Central Europe. ${ }^{65}$ This approach reflected Erdoğan's efforts at cultivating an 'image of working for the underprivileged and against the powerful [also] on the international stage. President Erdoğan likes to present himself and Turkey as the voice of a deprived global Muslim community against Western double standards'. ${ }^{66}$ By contrast, anti-Americanism cannot be observed in India's foreign policy under Modi. His government continued the rapprochement with Washington initiated by his predecessors Manmohan Singh and Atal Bihari Vajpayee. Here, both India's structural position in international affairs and Modi's Hindu-nationalist thick ideology are important. On the one hand, India's status seeking as a rising power ${ }^{67}$ feeds into a desire to be accepted as a partner by Washington. On the other, Modi's pro-US stance reflects his efforts in eradicating some of the core ideological tenets of the Congress party - primarily its 'Nehruvian' anti-imperialism and anti-Americanism, which has profoundly shaped India's foreign policy since independence. ${ }^{68}$

Anti-Americanism has a long tradition in Latin America (and beyond) and thus is not peculiar to populism. Nonetheless, the patterns of shifting relations with the US reflect populist governments' desire to show their voters that they are willing to (more or less radically) break with past ideologies and policies adopted by their predecessors. Therefore, it is unsurprising that anti-Americanism is easier to politicise in countries that are highly dependent on or have close ties with the US. This has been the case for Turkey, the Philippines, and even Venezuela, for whom the US was the largest oil importer and, before Chávez, weapons provider.

\footnotetext{
${ }^{60}$ See below and Leslie E. Wehner, 'Role expectations as foreign policy: South American secondary powers' expectations of Brazil as a regional power', Foreign Policy Analysis, 11:4 (2015), pp. 435-55.

${ }^{61}$ Ronald D. Sylvia and Constantine P. Danopoulos, 'The Chávez phenomenon: Political change in Venezuela', Third World Quarterly, 24:1 (2003), p. 70.

${ }^{62}$ Julio C. Teehankee, 'Duterte's resurgent nationalism in the Philippines: a discursive institutionalist analysis', Journal of Current Southeast Asian Affairs, 35:3 (2017), p. 69.

${ }^{63}$ Heydarian, The Rise of Duterte, p. 11. Interestingly, anti-Americanism also is a staple of European populists of different ideological backgrounds since, being 'the undisputed superpower ... populists [can] associate it with a variety of policies they oppose ... - free trade, loss of sovereignty, cultural homogenization, etc.' (Chryssogelos, 'Populism in foreign policy').

${ }^{64}$ Aydın Aylin Çakır and Gül Arıkan Akdağ, 'An empirical analysis of the change in Turkish foreign policy under the AKP government', Turkish Studies, 18:2 (2017), p. 347.

${ }^{65}$ Ibid., p. 352.

${ }^{66}$ Günay, 'Foreign policy as a source of legitimation', p. 43.

${ }^{67}$ Rajesh Basrur and Kate Sullivan de Estrada, Rising India: Status and Power (Abingdon and New York: Routledge, 2017).

${ }^{68}$ Sandra Destradi and Johannes Plagemann, 'Party Ideology and Change in Indian Foreign Policy', paper presented at the ECPR General Conference, Hamburg, August 2018. Additionally, the emergence of China as India's principal strategic challenge has made close relations with the US more palatable to an Indian audience that otherwise cherishes anti-American sentiments.
} 
Overall, populist government formations do not seem to lead to more aggressive or conflictprone foreign policies across the board. The dangers of populists using aggressive foreign policies for domestic mobilisation purposes are mitigated by their 'thick' ideologies and by the imperatives following from their countries' position in the international system.

\section{A weakening of international institutions and global governance?}

Among the worries most explicitly associated with the global rise of populism is that it will produce a weakening of the established international order with its international institutions and global governance. This is hardly surprising given European populists' widespread Euroscepticism - from right-wing populist parties like Fidesz in Hungary and PiS in Poland to, albeit more moderately, left-wing parties like PODEMOS in Spain. Episodes like Trump's withdrawal from the Paris accord on climate change mitigation suggest that populists in power will undermine global governance efforts and prove unwilling to contribute to the provision of global public goods.

Besides such anecdotal evidence from Western cases, there are theoretical reasons to expect populists in power to undermine international institutions and global governance mechanisms. For one, populism is often described as a backlash of a perceived growing influence of international bureaucracies ${ }^{69}$ and the weakening of the nation state at the hands of a transnational elite. And indeed, an incipient strand in the literature on the international dimensions of populism stresses how populism has emerged as a consequence of global developments, including the

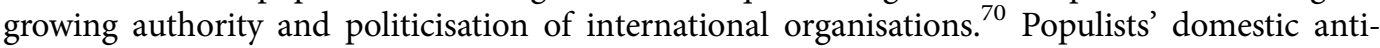
elitism would therefore likely dovetail with a disregard for transnational elites and allegedly elitist international institutions detached from the 'real people'. Populist leaders can be expected to perceive international institutions as limiting their government's room to manoeuvre or as threatening their country's much-valued national sovereignty. We therefore expect populists, once they form governments, to sideline such institutions as they do with intermediate institutions domestically. Moreover, the bashing of 'elitist' international institutions in the name of national sovereignty becomes an important instrument of domestic mobilisation for populist leaders. The 'leave' campaign for Brexit in the UK is the most glaring case in point. Italian Interior Minister Salvini explaining schoolchildren the notion of 'sovranismo' as independence from EU interference in a TV show is another example among many. ${ }^{71}$ However, such domestic mobilisation only works in countries that are deeply embedded in international institutions: only if citizens are aware of such institutions and potentially directly affected by them, will it be rewarding for populists to discursively construct international institutions as a threat.

Similarly, populist governments can be expected to be less willing to carry the costs of global public good provision as compared to non-populist governments. Indeed, in theoretical terms, we expect populists' focus on a narrowly defined 'people' to lead to a limited readiness to contribute to the wellbeing of those not belonging to it. The provision of global public goods by definition not just benefits the 'people', but allows others to free ride. Research on European populist radical right parties confirms that they tend to oppose global governance efforts on issues like climate change mitigation or development aid. ${ }^{72}$ However, there might be instances in which contributions to global governance entail substantial benefits of a different kind for a populist

\footnotetext{
${ }^{69}$ Michael Zürn, 'Global governance and legitimacy problems', Government and Opposition, 39:2 (2004), p. 285.

${ }^{70}$ Angelos Chryssogelos, 'State transformation and populism: From the internationalized to the neo-sovereign state?', Politics (2018), available at: \{doi: 10.1177/0263395718803830\}; Michael Zürn, 'How the taming of the class conflict produced authoritarian populism', Democracy Papers (17 April 2018), available at: \{https://items.ssrc.org/how-the-taming-of-the-classconflict-produced-authoritarian-populism/\} accessed 12 February 2019.

${ }^{71}$ CorriereTv, 'Salvini alla lavagna spiega la parola "sovranismo"', available at: \{https://video.corriere.it/salvini-lavagnaspiega-parola-sovranismo/751e9962-e6bd-11e8-b579-7cd18decd794?refresh_ce-cp\} accessed 22 November 2018.

${ }^{72}$ See Cas Mudde, Populist Radical Right Parties in Europe (Cambridge: Cambridge University Press, 2007).
} 
government. For example, rising powers might use global public goods provision to show that they behave as 'responsible' members of the international community by fulfilling the expectation that 'with power comes responsibility'. ${ }^{73}$ Moreover, populists' specific thick ideology may either reinforce or mitigate their scepticism of global governance in specific policy fields. For example, right-wing populists might be more inclined to make concessions on trade liberalisation as opposed to those espousing a leftist thick ideology.

And indeed, if we look at instances of populist government formations beyond the West, we find that the degree to which populists oppose international institutions varies depending on how deeply their countries are already embedded in such institutions as well as on populists' underlying 'thick' ideology. Take the case of Turkey, where an increasingly explicit rejection of international institutions has taken place since Erdoğan came to power. The country has been a member of NATO since 1952; it applied for membership in the European Economic Community in 1987, was recognised as a candidate for full membership in 1999, and started accession negotiations with the EU in 2005. As the Turkish government became more and more populist under Erdoğan, a remarkable process of gradual disengagement from international institutions took place. In their analysis of the agreements ratified by successive Turkish governments, Çakir and Akdağ find that the first AKP government until 2007 was still quite engaged in international institutions. However, a sharp decline in Turkey's relations with international organisations took place during the second and third AKP governments. ${ }^{74}$ This reflects Erdoğan's refocusing of foreign policy on the Middle East during the 2000s, and its growing distance from Western positions. The estrangement between Turkey and the West has also been related to the ever more evident anti-pluralist elements in Erdoğan's populism; in particular, the EU has grown increasingly critical of Erdoğan's repressive domestic policies, earning itself accusations of meddling with Turkey's domestic affairs.

India, the Philippines, and Venezuela have been less deeply involved in international organisations, thereby giving populists less opportunities to discursively construct international institutions and their transnational elites as the 'other' vis-à-vis the 'real people'. However, Duterte's strident opposition to international institutions was a result of perceived limitations to national sovereignty. It was in response to the UN's and EU's condemnations of his anti-drug crusade that Duterte criticised the European Union, ${ }^{75}$ threatened to quit, and 'burn down' the United Nations, and called the UN high commissioner for human rights a 'son of a bitch'. ${ }^{76}$ Yet, he has not torpedoed the Association of Southeast Asian Nations (ASEAN), of which the Philippines held the chairmanship in 2017, as this organisation has made non-interference in the domestic affairs of member states one of its core principles.

A focus on national sovereignty and non-interference has also been a driving force in Modi's approach to international organisations. However, in the case of India this has hardly been a break with the past, as all Indian governments have emphasised those principles. In general terms, Modi has kept alive India's traditional commitment to the United Nations, ${ }^{77}$ while retaining previous governments' sceptical approach to institutions like the World Trade Organization

\footnotetext{
${ }^{73}$ Kai Michael Kenkel and Sandra Destradi, 'Explaining emerging powers' reluctance to adopt intervention norms: Normative contestation and hierarchies of responsibility', Revista Brasileira de Política Internacional, 62:1 (2019), available at: \{doi: http://dx.doi.org/10.1590/0034-7329201900102\}.

${ }^{74}$ Aylin Aydın Çakır and Gül Arıkan Akdağ, 'An empirical analysis of the change in Turkish foreign policy under the AKP government', Turkish Studies, 18:2 (2017), pp. 350-2.

${ }^{75}$ Heydarian, The Rise of Duterte, p. 46.

${ }^{76}$ Felipe Villamor, 'Rodrigo Duterte of Philippines calls U.N. Human Rights Chief an "idiot”, The New York Times, available at: $\{$ https://www.nytimes.com/2016/12/22/world/asia/rodrigo-duterte-philippines-zeid-raad-al-hussein.html\} accessed 29 August 2018.

${ }^{77}$ Interestingly, Modi has been less keen than his predecessor to get a permanent Security Council seat for India, but he has emphasised the UN's pre-eminence as compared, for example, to the G-20. See Andrew F. Cooper and Asif B. Farooq, 'The role of China and India in the G20 and BRICS: Commonalities or competitive behaviour?', Journal of Current Chinese Affairs, 45:3 (2017), pp. 73-106.
} 
$(\mathrm{WTO})^{78}$ and their reluctant attitude vis-à-vis regional organisations like the South Asian Association for Regional Cooperation (SAARC). The (minor) shifts in India's approach to international institutions under Modi have been driven not by populism as such, but rather by the government's rejection of 'Nehruvianism' in line with its 'thick' Hindu-nationalist ideology. This was reflected in Modi's disengagement from the Non-Aligned Movement (NAM). The strategic need to keep an eye on Chinese activities in Asia has been another driving force of India's engagement in international organisations, as in the case of India's accession to the Shanghai Cooperation Organization (SCO) in 2017 and to the Chinese-initiated Asian Infrastructure Investment Bank (AIIB).

Hugo Chávez's approach to international institutions reveals that populists in power in some cases even promote them, if this fits with their thick ideology. Chávez actively undermined existing organisations dominated by the United States, most notably the Organization of American States (OAS), ${ }^{79}$ at the same time as he used alternative regional institutions to create a counterweight to the US. Chávez was instrumental in the foundation of the Alianza Bolivariana para América (ALBA) in 2006 and in related initiatives such as PetroAmérica with its regional oil companies like Petrocaribe. Moreover, he tried to expand Venezuela's influence in UNASUR and, together with Brazil, launched the South American Defence Council. Importantly, Chávez promoted a distinct brand of leftist, Bolivarian regionalism. Aided by the oil boom of 200309, he used regional cooperation as a tool to improve Venezuela's status in world politics and as a counterweight to US hegemony. ${ }^{80}$ In this case, we see that a populist takeover can lead to a selective rejection of existing international institutions, but also to new forms of engagement driven by thick ideology and status seeking.

Our analysis of populist government formation beyond Europe and the West therefore reveals that populism does not automatically lead to a rejection of international institutions. National sovereignty and independence are important guiding principles in all populists' foreign policies. However, since most countries in the Global South are less integrated in a thick web of international institutions as compared to Western states, opposition to international institutions only makes sense if national sovereignty is perceived as being curtailed.

Similarly, our cases reveal that populist government formation does not automatically lead to a wholesale rejection of global governance initiatives. ${ }^{81}$ Instead, the driving forces behind variations in the readiness to provide global public goods seem to be cost-benefit calculations as well as, in some instances, populists' thick ideology.

In the field of climate governance, for example, evidence is mixed. Chávez provided flamboyant rhetoric support for climate change mitigation policies, ${ }^{82}$ while pursuing an economic model based on oil extraction. Duterte followed a zigzagging approach to the Paris Agreement, initially arguing that he would not stick to an accord that was being used by rich nations to hamper the economic growth of developing countries. Ultimately he shifted his stance by stating that 'global warming was a "top priority" 83 and his government ratified the Paris Agreement. India's Prime Minister Modi surprised observers by softening the uncompromising approach of his

\footnotetext{
${ }^{78}$ Amrita Narlikar, 'India's role in global governance: a modi-fication?', International Affairs, 93:1 (2017), pp. 93-111.

${ }^{79}$ Carlos A. Romero and Víctor M. Mijares, 'From Chávez to Maduro: Continuity and change in Venezuelan foreign policy', Contexto Internacional, 38:1 (2016), p. 183.

${ }^{80}$ Sean W. Burges, 'Building a Global Southern coalition: the competing approaches of Brazil's Lula and Venezuela's Chávez', Third World Quarterly, 28:7 (2007), p. 1346.

${ }^{81}$ The assessment is based on an analysis of shifting engagements after populist takeover by Chávez, Erdoğan, Modi, and Duterte in the fields of climate governance, crisis management and peacekeeping, multilateral trade as well as development cooperation and humanitarian aid. Due to space constraints, findings can only be summarised here.

${ }^{82}$ Hugo Chávez, Speech at the XV International Conference of the United Nations Organization on Climate Change in Copenhagen, available at: $\{$ https://venezuelanalysis.com/analysis/5013\} accessed 27 November 2018.

${ }^{83}$ Ed King, 'Duterte: Addressing Climate Change Is “Top Priority” for Philippines', Climate Home News, available at: \{http://www.climatechangenews.com/2016/07/25/duterte-addressing-climate-change-is-top-priority-for-philippines/\} accessed 30 July 2018.
} 
non-populist predecessors to climate governance. At the Paris summit of 2015, Modi even tried 'to present [himself] as a facilitator of the Paris agreement [and] played a major role in pioneering a new agenda on renewable sources of energy. ${ }^{84}$ This was probably so for reasons related to prestige and status seeking: Modi's former Foreign Secretary Jaishankar justified India's new engagement on a set of global governance issues by arguing that 'an aspiring leading power, at a minimum, needs to expand its global footprint' and that India's initiatives in fields such as disaster relief and humanitarian assistance have 'increased respect for India as a global citizen'. ${ }^{85}$

In a similar vein, Erdoğan for some time made use of contributions to global governance for status seeking. Most notably, during its first and second term in office, the AKP government was involved in several mediation efforts in regional conflicts and crises, for example between Hamas and Fatah or Hamas and Israel. ${ }^{86}$ In 2010, the AKP government even promoted, together with Brazil, diplomatic efforts at reconciliation between Iran and the West over the nuclear issue. ${ }^{87}$ However, over time such contributions to international peacemaking waned. Turkey continued to provide troops to NATO and EU missions (for example, to the EUFOR ALTHEA mission in Bosnia and Herzegovina), but after 2007 its troop contributions to UN peacekeeping missions declined sharply. By contrast, India's UN peacekeeping troop contributions under Modi remained on levels comparable to those of the previous government, at least until $2017^{88}$

When it comes to engagements in multilateral trade regimes, we see that the formation of populist governments leads to shifts that are, overall, in line with respective thick ideologies: Erdoğan, Modi, and Duterte showed an increased willingness to open their economies to global markets, while leftist Chávez staunchly opposed the establishment of a US-led Free Trade Area of the Americas (FTAA). At the same time, conventional left-right distinctions are sometimes blurred in the Global South. Correspondingly, Chávez's Bolivarianism did not preclude regional economic integration, and a right-wing populist like Modi continued his predecessors' ambivalent approach to the WTO and even introduced new protectionist measures in $2018 .{ }^{89}$ Where the 'enemy of the people' and the 'predatory elite' are identified in domestic minorities (Kemalists, drug addicts, Muslims), liberal economic policies do not contradict populists' antielitist and anti-pluralist agendas. In need of foreign investments, right-wing populists in the Global South may find it opportune to open the economy. By contrast, where predatory elites are explicitly associated with 'neo-imperalism' and foreign (particularly US) business interests, populists' foreign trade policies rather support regional economic integration.

In fields like development cooperation and humanitarian aid, populist governments in 'new donors' like India or Turkey have introduced more instrumental approaches. Under Modi, aid expenditures declined slightly and India's understanding of foreign aid has become more mercantilist than under previous governments, ${ }^{90}$ while Erdoğan has reshuffled humanitarian aid to Muslim countries. ${ }^{91}$ For Chávez, by contrast, the notion of 'solidarity' was a key ideological principle, ${ }^{92}$ and foreign aid funded through oil revenues became an essential source of international influence.

\footnotetext{
${ }^{84}$ Narlikar, 'India's role in global governance', p. 104.

${ }^{85}$ Subrahmanyam Jaishankar, Indian Foreign Secretary Subrahmanyam Jaishankar's Remarks, Carnegie India, available at: \{http://carnegieindia.org/2016/04/06/indian-foreign-secretary-subrahmanyam-jaishankar-s-remarks/iwq8\} accessed 30 August 2018.

${ }^{86} \mathrm{Cop}$ and Zihnioğlu. 'Turkish foreign policy under AKP rule', p. 33.

${ }^{87}$ Ibid., p. 31.

${ }^{88}$ UN Peacekeeping, 'Troop and Police Contributors', available at: $\{$ https://peacekeeping.un.org/en/troop-and-police-contributors\} accessed 29 May 2018.

${ }^{89}$ Destradi and Plagemann, 'Party Ideology and Change in Indian Foreign Policy'.

${ }^{90}$ Rani Mullen and Kashyap Arora, 'India’s Development Cooperation: Analysis of the Union Budget 2016-2017', Centre for Policy Research, available at: \{http://www.cprindia.org/research/reports/analysis-union-budget\} accessed 11 June 2018.

${ }^{91}$ Kerim Can Kavakli, 'Domestic politics and the motives of emerging donors: Evidence from Turkish foreign aid', Political Research Quarterly (2018), available at: \{doi: 10.1177/1065912917750783\}.

${ }^{92}$ Romero and Mijares, 'From Chávez to Maduro', p. 174.
} 
Overall, these glimpses at populists' global engagements reveal that their focus on 'the people' at the domestic level does not necessarily translate either into a complete rejection of international institutions nor into a wholesale refusal to provide global public goods. Instead, status considerations or ideological commitments can induce populists to behave like 'good global citizens'.

\section{Centralisation and personalisation of foreign policymaking}

One of populism's core features is the claim by individual populist politicians to be the only true representatives of the 'people' and to embody the 'popular will'. Foreign policy, and diplomacy in particular, is the domain of an exceptionally elitist and exclusive community, comprised of unelected foreign policy bureaucrats, (often second-tier) politicians and academic think tankers. For populists, the global perspective heralded by such elites epitomises the distance between the people and their government. Not only are many foreign policy issues beyond the concern of ordinary citizens, but complex diplomatic protocol and etiquette, with their roots in fifteenthcentury European traditions, further add to the impression of a detachment of foreign affairs from the 'true' people. Hence, one can expect populist leaders to at the very least disempower those elements of the foreign policy community most representative of elitism and globalism: diplomats. Moreover, previous studies have found that '[o]ver-centralization of power' in Turkey and Argentina is an important commonality of otherwise differing populists in power. ${ }^{93}$ Likewise, Plagemann and Destradi found that the procedural aspects of foreign policy decision-making have been the most significant change following the transfer of power from a non-populist to a populist government in India. ${ }^{94}$ Thus, we expect that the formation of populist governments leads to a side-lining of foreign ministries and a centralisation of foreign policy decision-making with the populist leader and a small circle of advisors.

The centralisation and personalisation of foreign policy in the hands of heads of states or governments is not unique to populist governments but constitutes a broader trend. ${ }^{95}$ Yet, we argue that the kind of centralisation promoted by populist leaders in government differs from centralisation elsewhere. Centralisation under populist leaders is not only more pronounced but also more personal. The anti-pluralist dimension of populism entails the claim that only the populist leader - and nobody else - can speak in the name of the 'true' people. As a consequence, the populist leader will be more personally involved in foreign policymaking as opposed to nonpopulist predecessors. Once populists form governments, the bureaucracy may remain in place, but we can expect it to be marginalised. The route to the populist leader's ear will likely go less through standardised channels of communication and more through personal or family bonds, or party affiliation. Populist leaders can be expected to work with small groups of advisors, most likely not recruited from traditional foreign policy elites. At the same time, populist leaders may be induced to trust more in their personal relations with other world leaders, rather than in other formalised ways of bilateral communication, from ambassadors to line ministries' contacts.

The many instances of erratic foreign policy decisions by populist leaders like Trump can be traced back to such centralisation and personalisation of foreign policymaking. Indeed, in theoretical terms, populists' immediate relation to their 'people' (credible or not) may result in unexpected foreign policy moves based less on past precedence and more on their personal perceptions of popular sentiments. Thereby, the personalisation of foreign policymaking may contribute to the politicisation of foreign policy, as well as to its greater contingence on individual

\footnotetext{
${ }^{93}$ S. Erdem Aytaç and Ziya Öniş, 'Varieties of populism in a changing global context: the divergent paths of Erdoğan and Kirchnerismo', Comparative Politics, 47:1 (2014), p. 56.

${ }^{94}$ Plagemann and Destradi, 'Populism and foreign policy'.

${ }^{95}$ See, for instance, Andrew F. Cooper, 'The changing nature of diplomacy', in Andrew Cooper, Jorge Heine, and Ramesh Thakur (eds), The Oxford Handbook of Modern Diplomacy (Oxford: Oxford University Press, 2013), p. 36.
} 
leaders' perceptions and personality traits. Accordingly, Drezner suggests that populism asks for a more profound incorporation of leaders' personalities in the study of foreign policy and international relations. ${ }^{96}$

However, the effects of such personalisation might be mitigated by populists' 'thick' ideology. If populists embrace a full-fledged and consistent thick ideology with clear prescriptions for the field of international politics, they will rather stick to it and will avoid sudden turnarounds that might undermine their credibility. By contrast, populist leaders who are not bound by a strict 'thick' ideological frame, will have greater freedom to politicise foreign policy or to engage in shocking moves to impress a domestic audience.

Our cases from the Global South confirm our expectations about the centralisation and personalisation of foreign policymaking. In all of them, after the formation of populist governments, traditional foreign policy elites were sidelined. Chávez surrounded himself with a group of likeminded advisors, whose 'determined agency ${ }^{\text {'97 }}$ led to substantial foreign policy outcomes, such as the creation of ALBA. The AKP openly used an anti-elitist argument to centralise foreign policy by stating 'that the Turkish foreign policy had been the work of an alienated Westernizing/ Westernist elite, who believed in the possibility of a successful civilizational shift towards the West, who lacked interest and knowledge about the native geography and culture, and who therefore could not grasp Turkey's potentials stemming from its geopolitical and historical depths in the region'. 98

In Modi's India, relations with China and Pakistan have become the domain of Amit Doval, a former police and intelligence officer, and current National Security Advisor (a post that was typically occupied by diplomats) who also served as first director of the Vivekananda International Foundation, a BJP-affiliated think tank. Meanwhile, the traditionally immensely powerful foreign policy bureaucracy within the Ministry of External Affairs has been marginalised in both mundane (planning foreign visits) as well as more substantial issues (relations with China). Yet, the Indian case also reveals how personalisation might reinforce the predominance of the populist government's thick ideology. Nehruvian ideas had dominated the foreign policy establishment since independence. ${ }^{99}$ Under Modi, they have been gradually replaced by what some have called a 'hyper-nationalist' foreign policy discourse rooted in Hindu nationalism. ${ }^{100}$ In such a scenario, centralisation serves as a tool to overcome (ideological) path dependencies.

But to what extent did centralisation and personalisation lead to sudden foreign policy turns and to greater unpredictability? In our cases, there are several instances of surprising or offensive behaviour in international affairs. Chávez, for instance, famously called US President George W. Bush a burro (donkey) and, in a public speech, suggested Venezuela was prepared to aid Bolivia's President Evo Morales with machine guns in case of a coup. Unsurprisingly, such remarks aroused considerable diplomatic tensions. Likewise, Duterte's insults of US President Obama, or Erdoğan's unexpected public threat in 2010 to expel 100,000 Armenians living in Turkey, ${ }^{101}$ have had serious foreign policy implications.

However, our cases also reveal that the potential unpredictability deriving from personalisation has been mitigated by the 'thick' ideologies espoused by populists in power. As outlined above,

\footnotetext{
${ }^{96}$ Drezner, 'The angry populist as foreign policy leader'.

${ }^{97}$ Diana Raby, 'Venezuelan foreign policy under Chávez, 1999-2010: the pragmatic success of revolutionary ideology?', in Gian Luca Gardini and Peter Lambert (eds), Latin American Foreign Policies - Between Ideology and Pragmatism (New York: Palgrave, 2011), p. 160.

${ }^{98}$ Menderes Çinar, 'Turkey's “Western” or “Muslim” identity and the AKP’s civilizational discourse', Turkish Studies, 19:2 (2018), p. 12.

${ }^{99}$ Ian Hall, 'The persistence of Nehruvianism in India's strategic culture', in Ashley J. Tellis, Alison Szalwinski, and Michael Wills (eds), Strategic Asia 2016-17 (Seattle: National Bureau of Asian Research, 2016), pp. 141-67.

${ }^{100}$ Thorsten Wojczewski, India's Foreign Policy Discourse and its Conceptions of World Order (New York: Routledge, 2018).

${ }^{101}$ Aylin Ş. Görener and Meltem Ş. Ucal, 'The personality and leadership style of Recep Tayyip Erdoğan: Implications for Turkish foreign policy', Turkish Studies, 12:3 (2011), p. 376.
} 
Turkish foreign policy under Erdoğan has shifted from a pro-Western to a more anti-Western outlook - certainly a consequential foreign policy change. Yet, much of this can be explained by reference to the AKP's thick ideology, rather than the personalisation of foreign policymaking. In fact, Erdoğan's political Islam always foresaw a realignment of Turkey's foreign relations towards its eastern European, Asian, and Middle Eastern neighbours. Moreover, Erdoğan's political rhetoric for long-included elements of demonisation of the West and Westernised elites against the religious, morally superior people. ${ }^{102}$ Similarly, Chávez introduced substantial foreign policy changes - from the renationalisation of the oil industry, to replacing the US with Russia as Venezuela's main defence partner, and the successful opposition to a US-led free trade arrangement at the height of the 'unipolar moment'. But these shifts should not necessarily be traced back to his personality. They rather reflected the implementation of the core tenets of his strong and consistent thick ideology of a Bolivarian revolution. In a similar way, the limited foreign policy changes throughout Modi's first term in office - a somewhat more 'muscular' approach to Pakistan and China or his outreach to the Indian diaspora - are much in line with Hindu nationalist thinking. ${ }^{103}$

By contrast, Duterte's rapprochement with China against the backdrop of competing maritime claims in the South China Sea appears to be a stronger case for a populist's personalisation of foreign policy matters. To the surprise of most, including his own cabinet officials, ${ }^{104}$ Duterte played down a 2016 ruling of the Permanent Court of Arbitration in The Hague that justified the Philippines' claims. On state visit to Beijing, he publicly 'bid "goodbye" to and vowed strategic "separation" from America' before his enchanted hosts. ${ }^{105} \mathrm{He}$ then offered to 'realign the Philippines with China's "ideological flow", beckoning a new alliance against the West"106 - all of this ostensibly in return for Chinese investments and support for his anti-drug campaign. While Duterte's anti-American impulses have been a constant feature of his for decades, ${ }^{107}$ overall the absence of an unequivocal 'thick' ideological line on his part renders contemporary Philippine foreign policy engagements less predictable.

The impact of populists' centralisation and personalisation of foreign policy decision-making is therefore mitigated by the strength and coherence of their thick ideology. Unpredictability is not an automatic consequence of populist government formation. However, centralisation and personalisation might have two other, longer-term and more indirect consequences.

First, the marginalisation of established foreign policy apparatuses ${ }^{108}$ might be met by resistance from the diplomatic corps and other section of the bureaucracy, thereby causing problems of implementation. ${ }^{109}$ Effectiveness of a given foreign policy may also suffer from the lack of expertise of advisors recruited outside the foreign policy establishment. ${ }^{110}$

Second, personalisation inevitably incorporates strong elements of prioritisation by the populist leader. A small (and possibly homogeneous) group of advisors will only be able to focus on a select number of issues with direct links to the populist leader's agenda. This will allow populists to get things done - think of Chávez's vigorous regional diplomacy. However, the flipside of such prioritisation may well be that foreign policy issues of less importance to the leader and their small circle of advisors will continue to be resolved by standard procedures - or not at all. In

\footnotetext{
${ }^{102}$ Birol Başkan, 'Islamism and Turkey's "foreign policy during the Arab Spring”, Turkish Studies, 19:2 (2018), p. 281; H. Bahadir Türk, 'Populism as a medium of mass mobilization: the case of Recep Tayyip Erdoğan', International Area Studies Review, 21:2 (2018), p. 160.

${ }^{103}$ Destradi and Plagemann, 'Party Ideology and Change in Indian Foreign Policy'.

${ }^{104}$ Heydarian, The Rise of Duterte, p. 48.

${ }^{105}$ Ibid.

${ }^{106}$ Ibid.

${ }^{107}$ Ibid.

${ }^{108}$ Görener and Ucal, 'The personality and leadership style of Recep Tayyip Erdoğan', p. 376.

${ }^{109}$ On this point for Venezuela, see Raby, 'Venezuelan foreign policy under Chávez, 1999-2010', p. 160.

${ }^{110}$ This point was made in the authors' personal communication with two anonymous Indian experts in 2017.
} 
fact, research on (and one of these authors' experience in) bureaucratic politics strongly suggests that a lack of leader-level interest in particular foreign policy issue areas will result in stasis. ${ }^{111}$ Without the populist leader's backing, solutions in controversial issue areas beyond his or her focus will be more difficult to achieve. Related to this is the creation of bottlenecks. According to Western diplomatic sources, day-to-day dealings with New Delhi have become more complicated under Modi precisely because MEA officials at times are unable to take decisions and the Prime Minister's Office is difficult to reach. ${ }^{112}$ Other experts point at the enormous discrepancy between leader-level announcements and implementation (for instance, in Modi's Act East initiative) as a potential consequence of personalisation. ${ }^{113}$

\section{Populism's longer-term consequences for world politics: (Un-)predictability, personalisation, and the reinforcement of existing trends}

What does the preceding analysis tell us about the global rise of populism and its implications for world politics in the medium and long term? Our assessment of cases from the Global South revealed that the formation of populist governments does not automatically lead to more conflictive foreign policies or to a weakening of international institutions and global governance. While there are theoretical reasons to expect populists to politicise foreign policy for domestic mobilisation, such implications of populism will be mitigated by other factors: by a countries' position in the international system and a corresponding need for status seeking and recognition; by the degree of embeddedness in international institutions; and by populists' thick ideologies. The most immediate effect of populism concerns procedural aspects, as populists privilege a centralisation and personalisation of foreign policy decision-making.

Based on these findings, this section will discuss some broader, cross-cutting trends. In particular, we question whether the global rise of populism should induce us to expect and theorise: (1) a growing unpredictability in international affairs; (2) a renewed centrality of single leaders and their personality traits; and (3) a radical reconfiguration of world politics as such.

As stated in the introduction, gloomy commentary and experiences from Western cases suggest a growing unpredictability in world affairs as a consequence of populists' rise to power. From the outset, the centralisation and personalisation of foreign policy seems to justify such fears. After all, personalisation can make foreign policy the subject of snap judgements by leaders either unwilling to follow past precedence in their country's foreign relations or simply unaware of it. Moreover, populists typically portray politics in terms of 'crisis, danger, and uncertainty' ${ }^{114}$ and promise radical ruptures with the past in order to remedy such dismal circumstances. What follows from the notion of dramatically subverting established policies is obviously unpredictability. As one commentator put it, 'Chávez practices democracy as a regime of controlled chaos.'.15 Likewise, Erdoğan is described as a populist leader who 'uses the element of surprise in a very successful manner.' ${ }^{116}$ Prior to his inauguration as prime minister in 2003 and until around 2007, he ardently campaigned for EU membership, but by 2018 he accused the West of waging 'economic war' against Turkey and threatened to abandon his country's decade old security partnership. ${ }^{117}$ Thus, given foreign policy's greater dependence on populist leaders' personalities and

\footnotetext{
${ }^{111}$ Iver B. Neumann, “'A speech that the entire ministry may stand for”, or: Why diplomats never produce anything new', International Political Sociology, 1:2 (2007), p. 196.

${ }^{112}$ Personal communication with a senior European diplomat in March 2018.

${ }^{113}$ Personal communication with an anonymous Indian expert in November 2018.

${ }^{114}$ Nicole Curato, 'Politics of anxiety, politics of hope: Penal populism and Duterte's rise to power', Journal of Current Southeast Asian Affairs, 35:3 (2016), p. 91.

${ }^{115}$ Ivan Krastev, 'Democracy's “doubles”, Journal of Democracy, 17:2 (2006), p. 53

${ }^{116}$ Türk, 'Populism as a medium of mass mobilization', p. 159.

${ }^{117}$ Recep T. Erdoğan, 'How Turkey sees the crisis with the US', The New York Times (10 August 2018), available at: \{https:// www.nytimes.com/2018/08/10/opinion/turkey-erdogan-trump-crisis-sanctions.html\} accessed 29 August 2018.
} 
their characteristic calls for radical change, outside observers and other governments may find it more difficult to develop reliable expectations of future behaviour.

Yet, as argued above, a closer look at individual cases reveals the extent to which centralisation and personalisation are mitigated by populists' thick ideologies, thereby pointing us towards a more nuanced argument concerning populism's impact upon the predictability of world politics: a better understanding of populists' varying ideological stances - rather than only personal leadership characteristics or the thin ideology of populism - will render world politics more predictable. This, in turn, requires IR scholarship to engage with (non-Western) political ideologies more deeply than it has been the case so far.

Also, populist leaders' personality traits do not seem to matter in a consistent manner. This is so despite a now common conviction in policy circles that leader-level chemistry has become paramount for constructive bilateral relations. Modi's diplomacy, for instance, typically involves personal elements, from greeting world leaders at the airport, to exchanging clumsy hugs and jointly visiting his constituency in northern India. Yet, although not irrelevant, the importance of leader-level chemistry for world politics seems to be grossly overstated. For one, populists do not necessarily sympathise with each other. Whereas Chávez deepened relations with fellow populist Ahmadinejad's Iran, and Trump expressed his sympathy for Duterte at several occasions, neither Modi nor Erdoğan have developed noteworthy bonds with other populist leaders. Moreover, the most fundamental changes in populists' foreign policies were rather reflective of thick ideologies as well as larger trends (see below), and not so much of leaders' personality traits. The centrality of single populist leaders and their distinct personalities should therefore not be overestimated when we study the impact of populism on world politics.

Finally, our findings reveal that populists in power do not necessarily completely change the foreign policy course of their countries. They rather tend to reinforce pre-existing trends in international affairs - even though they may certainly do so more radically or express themselves in more extreme ways than their non-populist predecessors. Some of the more significant changes in the foreign policies of populists in power - Duterte's rapprochement with China, Erdoğan's turn away from the EU, and Chávez's turn towards fellow Latin American countries as well as Russia and China - are less of an indicator of erratic turnabouts than they are a reflection of today's international relations' multipolar character. Overall, populists in the Global South have tended to differentiate their countries' foreign relations, building up new international partnerships while weakening (but not entirely abandoning) links to traditional Western partners. This approach reflects the fact that South-South relations have become dramatically more important to these economies, as illustrated in the absolute growth of South-South trade and developing countries' growing share of global trade. ${ }^{118}$ In the meantime, the attraction of Western liberal democracies has waned. More than ever, great power relations are characterised by the simultaneity of cooperation and competition, and this new complexity entails institutional fragmentation and polycentric alliance building. ${ }^{19}$ The tendency towards 'multi-alignment', as it has been called in the case of India, ${ }^{120}$ is in line with broader trends in an increasingly multipolar world, but it also reflects populists' focus on national sovereignty and a related desire not to be excessively dependent on single international partners. ${ }^{121}$ Interestingly, a diversification of foreign

\footnotetext{
${ }^{118}$ UNCTAD, Trade and Development Report 2017 (New York and Geneva: UNCTAD, 2017).

${ }^{119}$ Amitav Acharya, 'The future of global governance: Fragmentation may be inevitable and creative', Global Governance, 22:4 (2016), pp. 453-60.

${ }^{120} \mathrm{Hall}$, 'Multialignment and Indian foreign policy under Narendra Modi'.

${ }^{121}$ However, defending state sovereignty and self-determination for long has been an important element in the foreign policies of countries in the Global South. In the non-aligned movement and within individual countries' foreign policy discourses, sovereignty effectively served as an emblem of equal international status and a defence against northern and former colonial powers' intrusion into domestic affairs. See, for instance, Barry Buzan, 'Universal sovereignty', in Tim Dunne and Christian Reus-Smit (eds), The Globalization of International Society (Oxford: Oxford University Press, 2017), p. 239.
} 
partnerships and a rapprochement to actors like Russia and China has also been a feature of some European populists such as the Fidesz government in Hungary.

Besides the diversification of international partnerships, the global rise of populism also reinforces a trend that sees (thick) ideologies (re)gaining importance in world affairs. In fact, the adoption of ideologies with specific cultural attributes - rather than a mere self-ascription to some point along the left/right continuum - has become a common feature of populist and nonpopulist governments alike. Consider the now frequent references to Confucianism in Chinese foreign policy discourses. ${ }^{122}$ In the words of one commentator, geopolitics today exacerbate cultural and religious differences: 'as group differences melt down in the crucible of globalization, they have to be artificially reinvented in more blunt and ideological form by, as it turns out, the communications revolution. It isn't the clash of civilizations so much as the clash of artificially reconstructed civilizations that is taking place. ${ }^{123}$ Such thick ideologies and the thin ideology of populism mutually reinforce each other. Chávez' anti-imperialism, for instance, was as much a result of his leftist thick ideology as it was of his populism, which discursively associated the US with a predatory domestic elite. ${ }^{124}$ Moreover, engaging the diaspora chimes particularly well with rightist thick ideologies in combination with populists' reference to the people and their embodiment in the populist leader.

\section{Conclusion}

Evidence from the Global South suggests that the systemic consequences of the global rise of populism for world affairs are less pronounced than one would expect from both news coverage of Western cases and the domestic effects of populism. Yet, our analysis also points at subtler but possibly not less consequential - ways through which populism definitely has an impact upon world politics. Such impact is mitigated by domestic factors (especially by populist governments' thick ideologies) as well as by structural factors (especially countries' embeddedness in international institutions, their position in the international system, and related status concerns).

Other than Verbeek and Zaslove, ${ }^{125}$ we argue that there are some genuinely populist traits in foreign policy. Populists centralise and personalise decision-making, they seek to differentiate their international relations away from exclusive alliances, and they reinforce a trend towards multipolarity and the centrality of specific thick ideologies. What emerges is a fluid and less intelligible international order, not a radical reconfiguration of world politics driven by populists' 'anti-globalism'. ${ }^{126}$

When it comes to the interaction of the thin ideology of populism with specific thick ideologies, our findings reveal that populism does not primarily and most profoundly affect the content or substance of foreign policy. For the thin ideology of populism to have an effect on the substance of foreign policy, proximity is important - in terms of geography, a shared political history, or economic dependency. As with the embeddedness in international organisations, scapegoating other countries only makes sense if close linkages relevant for the respective domestic populist template exist. Where this is the case, for example, the Turkish diaspora in Germany or India's Muslim minority, populism may greatly contribute to more conflictive relations (with

\footnotetext{
${ }^{122}$ Nicola Nymalm and Johannes Plagemann, 'Comparative exceptionalism: Universality and particularity in foreign policy discourses', International Studies Review, Online First (2018), available at: \{https://doi.org/10.1093/isr/viy008\}.

${ }^{123}$ Robert Kaplan, The Return of Marco Polo's World (New York: Random House, 2018), p. 221.

${ }^{124}$ Note that the employment of a confrontational foreign policy as a regime legitimation device is not restricted to populist regimes but, instead, a frequent tool in the legitimation strategies of autocratic regimes, particularly those under internal stress. See Heike Holbig, 'International dimensions of legitimacy: Reflections on Western theories and the Chinese experience', Journal of Chinese Political Science, 16:2 (2011), pp. 161-81.

${ }^{125}$ Verbeek and Zaslove, 'Populism and foreign policy'.

${ }^{126}$ Also see Thorsten Wojczewiski, 'Populism, Hindu nationalism, and foreign policy in India: the politics of representing "the people", International Studies Review (2019), available at: \{doi: 10.1093/isr/viz007\}.
} 
Germany and Pakistan, respectively); where this is absent, continuity - or foreign policy imperatives derived from the respective thick ideology - prevails. For instance, India's relations with the US remained fairly constant across populist and non-populist governments on both sides. This was due to Hindu nationalism's ideological affinity to the US as well as to New Delhi's previous relative independence from Washington. Hence, a closer interrogation of populists' thick ideologies not only reduces unpredictability but also helps in making sense of the so far understudied relationships between populists in the Global South and their counterparts in the Global North.

Acknowledgements. We are most grateful to Cordula Tibi Weber, without whose excellent research assistance this article would not have been possible. We also would like to thank three anonymous reviewers for their extremely helpful comments and suggestions. Earlier versions of this work were presented at a seminar on populism at the GIGA, at the DVPW conference (Frankfurt, September 2018), and at the RIS workshop 'Populism and International Relations' (University of Stellenbosch, September 2018). We are grateful to participants, and particularly to Florian Grotz, Klaus Brummer, Sophie Harman, Ruth Blakeley, Saskia Ruth-Lovell, and Hakkı Taş for helpful comments and feedback.

Prof. Dr Sandra Destradi is a Professor of International Relations and Regional Governance at the Helmut Schmidt University/University of the Federal Armed Forces Hamburg. She is also the Head of the Research Programme 'Power and Ideas' at the GIGA German Institute of Global and Area Studies. Her current research interests include rising powers' approaches to regional and global governance and the impact of the global rise of populism on world politics. Her research has been published, among others, in journals such as the European Journal of International Relations; Review of International Studies; Democratization; and Asian Survey. Author's email: sandra.destradi@giga-hamburg.de

Dr Johannes Plagemann is a political scientist and research fellow at the GIGA German Institute of Global and Area Studies. At the GIGA, he is the spokesperson of the research team 'Ideas and Agency' and coordinator of the DFG research project 'Legitimate Multipolarity' (2018-21). Dr Plagemann works on rising powers in international politics and Indian foreign policy in particular. In his latest research he focuses on (1) how populism affects foreign policy and (2) the legitimacy of international organisations in a multipolar world. He is the author of Cosmopolitanism in a Multipolar World (Palgrave Macmillan, 2015). His work has been published in, among others, International Studies Review; Foreign Policy Analysis; International Relations of the Asia Pacific; and Globalizations. Author's email: johannes.plagemann@giga-hamburg.de

Cite this article: Destradi, S., Plagemann, J. 2019. Populism and International Relations: (Un)predictability, personalisation, and the reinforcement of existing trends in world politics. Review of International Studies 45, 711-730. https://doi.org/ $10.1017 /$ S0260210519000184 